\title{
RESEARCH OF MIDSEASON POTATO VARIETIES SUITABLE FOR ORGANIC GROWING
}

\author{
Orsolya PAPP ${ }^{1}$, Timea Jung ${ }^{1}$, DORA DREXleR ${ }^{1}$ \\ ${ }^{1}$ Hungarian Research Institute of Organic Agriculture (ÖMKi) \\ 1033 Budapest, Miklós sq.1. Hungary \\ orsolya.papp@biokutatas.hu
}

\begin{abstract}
An essential issue in organic potato production is choosing the right varieties, because varieties grown under conventional conditions may not always be suitable for organic production. The choice of variety was based solely on farmers' experience, as research results were not available. Because of the lack of reliable information, ÖMKi initiated an on-farm research program for organic potato production in 2012.

$13 \mathrm{mid}$-season potato varieties with certain degree of resistance to relevant diseases or abiotic stresses were tested on 22 organic farms (2012-2015) in close cooperation with the growers. Quantitative and qualitative parameters were assessed at harvest. The average yield was $2.19-3.45 \mathrm{~kg} / \mathrm{m}^{2}$ (21-34 t/ha). Among seven qualitative parameters the most relevant quality problems were: Streptomyces and Rhizoctonia infection and damage by insect pests. No significant differences could be shown among the varieties regarding the assessed parameters, but disease resistance often differed compared to the descriptions provided by the seed tuber distributors.

Besides summarizing and sharing research results, regular meetings and field trips were arranged for farmers. As an indirect result of the on-farm research program the communication was highly improved among the participants and a well-working organic potato workgroup was formed.
\end{abstract}

Keywords: potato, Streptomyces, soil pH, Rhizoctonia, resistance

\section{INTRODUCTION}

Until recently potato varieties grown by Hungarian organic potato growers were the same as used in conventional agriculture, although not all of these varieties may be suitable for organic growing. The choice of variety was based solely on farmers' experience, as research results were not available. Unlike in other European countries, organic potato trials are not widespread in Hungary, until 2012 only one trial has been done (KOVÁCS ET AL., 2006). Moreover, certified organic potato cropping area in Hungary is relatively small, the communication and cooperation among stakeholders is relatively weak.

To fill the knowledge gap and to increase the communication among Hungarian organic potato growers, an on-farm participatory research program was run by ÖMKi in 20122015. The approach of on-farm participatory research was unknown in Hungary before, the introduction and adaptation was based on similar research network of FiBL Switzerland and FiBL Austria (Bio-Net AT).

\section{MATERIAL AND METHOD}

\section{Methodology of trials}

The trials were conducted as part of the on-farm participatory research program of ÖMKi, with 22 cooperating organic farms in several growing regions in Hungary (Figure 1). The size and character of the farms were either small, garden-scale micro farms cultivated by hand-driven methods, or mechanized farms using arable rotation and machinery. 


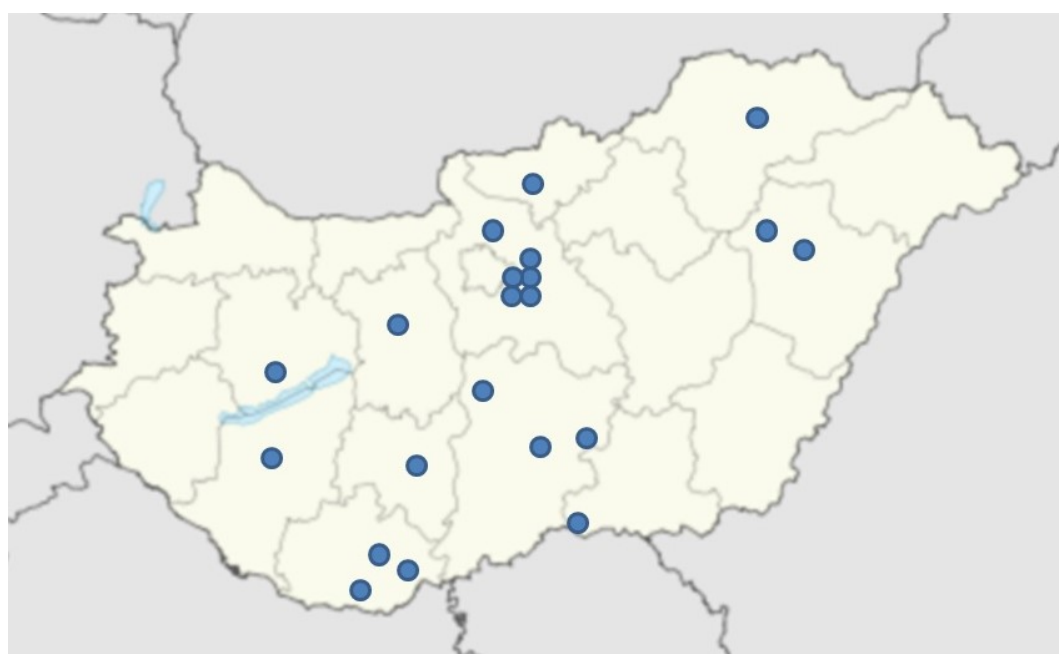

Figure 1. Organic farms participating in the potato on-farm participatory research program in Hungary, 2012-2015

A common midseason cultivation method was proposed to growers involved in the trials: The minimum size of the test plots was $12 \mathrm{~m}^{2}$ for each variety in the garden-scale farms (60 tubers were planted per variety), in arable farms the size of parcels were adjusted to the size of the field and the type of available machines. The spacing of plants was generally $70 \times 30 \mathrm{~cm}$. The tubers were usually planted in mid-April. Irrigation was recommended but depended on the abilities of each farm. Plant protection solutions were also recommended, but the exact system was chosen by the farmers: usually copper was used against Phytophtora, Bacillus thuringiensis var. tenebrionis or spinosad against potato beetle, and some of them also used plant conditioner materials. The harvest usually happened in August-September, after the foliage had withered. Fertilization was conducted according to general organic practices.

Although a common midseason cultivation method was proposed, the participating farmers determined their own production methods throughout the year, so smaller differences appeared. For the comparability of data, only those farms' data were processed and summarized that adapted the proposed midseason potato cultivation method. Therefore, out of 47 data series of 22 farms only 28 data series of 12 farms were analysed statistically. The remaining 19 data series could not be analysed because unforeseen vis maior events, discrepancies or missing soil data.

\section{Tested varieties}

Varieties with certain degree of resistance to relevant diseases or abiotic stresses were chosen for testing. The variety selection was based on Hungarian bred varieties in 2012, but the selection was modified year by year, according to trial results (Table 1). The seed tubers were not treated with any material before planting.

\section{Methodology of assessments}

The details of each year's cultivation were recorded by the farmers. Quantitative and qualitative parameters of 13 midseason potato varieties were assessed. At the end of harvest yield was recorded by farmers $\left(\mathrm{kg} / \mathrm{m}^{2}\right)$. Unsorted samples of 50 tubers were taken from each test plot of each variety. We conducted a visual inspection of the tubers' surface and recorded infections by Streptomyces, Rhizoctonia, Fusarium, Erwinia; severe damage by pests and by harvesting equipment. Deformed and greened tubers were also recorded. The presence of quality problems was recorded not the degree of the damage. 
Table 1. The list of potato varieties tested in 2012-2015

\begin{tabular}{|c|c|c|c|c|c|}
\hline Nr. & Variety name & $\mathbf{2 0 1 2}$ & $\mathbf{2 0 1 3}$ & $\mathbf{2 0 1 4}$ & $\mathbf{2 0 1 5}$ \\
\hline 1 & Arany Chipke & & & & $\mathrm{x}$ \\
\hline 2 & Barna & & & & $\mathrm{x}$ \\
\hline 3 & Bettina & & & $\mathrm{x}$ & \\
\hline 4 & Big Rossa & & & $\mathrm{x}$ & \\
\hline 5 & Dalida & & $\mathrm{x}$ & & \\
\hline 6 & Démon & $\mathrm{x}$ & $\mathrm{x}$ & $\mathrm{x}$ & $\mathrm{x}$ \\
\hline 7 & Desirée & $\mathrm{x}$ & & & \\
\hline 8 & Hópehely & $\mathrm{x}$ & $\mathrm{x}$ & $\mathrm{x}$ & \\
\hline 9 & Katica & $\mathrm{x}$ & & & \\
\hline 10 & Shannon & & & & $\mathrm{x}$ \\
\hline 11 & Tiamo & & $\mathrm{x}$ & $\mathrm{x}$ & \\
\hline 12 & Vénusz Gold & $\mathrm{x}$ & & & \\
\hline 13 & White Lady & $\mathrm{x}$ & & & \\
\hline
\end{tabular}

\section{Methodology of statistics}

Different statistical analyses were applied in order to identify differences among potato varieties regarding quality issues, and to find connections between yield and other environmental measures, such as soil $\mathrm{pH}$ levels. Therefore, correlation and variance analysis were used. The former analysis is a measure of the strength and direction of the relationship between variables. Since the used variables were either ordinal variables, or their distribution was not bivariate normal, the Spearman's rank-order (often abbreviated to Spearman's correlation) method was chosen to calculate a coefficient, $r_{s}$. Because of the same reason, the variance analysis methods used were either the Mann-Whitney U test, which is a rank-based nonparametric test, or the Kruskal-Wallis H test, if there were more than two groups of independent variables.

\section{RESULTS}

\section{Results of quantitative parameters (yield)}

The average yield of varieties varied according to climatic conditions of the growing season, but ranged between 2.1-3.4 kg/m² (21-34 t/ha). There were no significant differences between the trial years' average yield results.

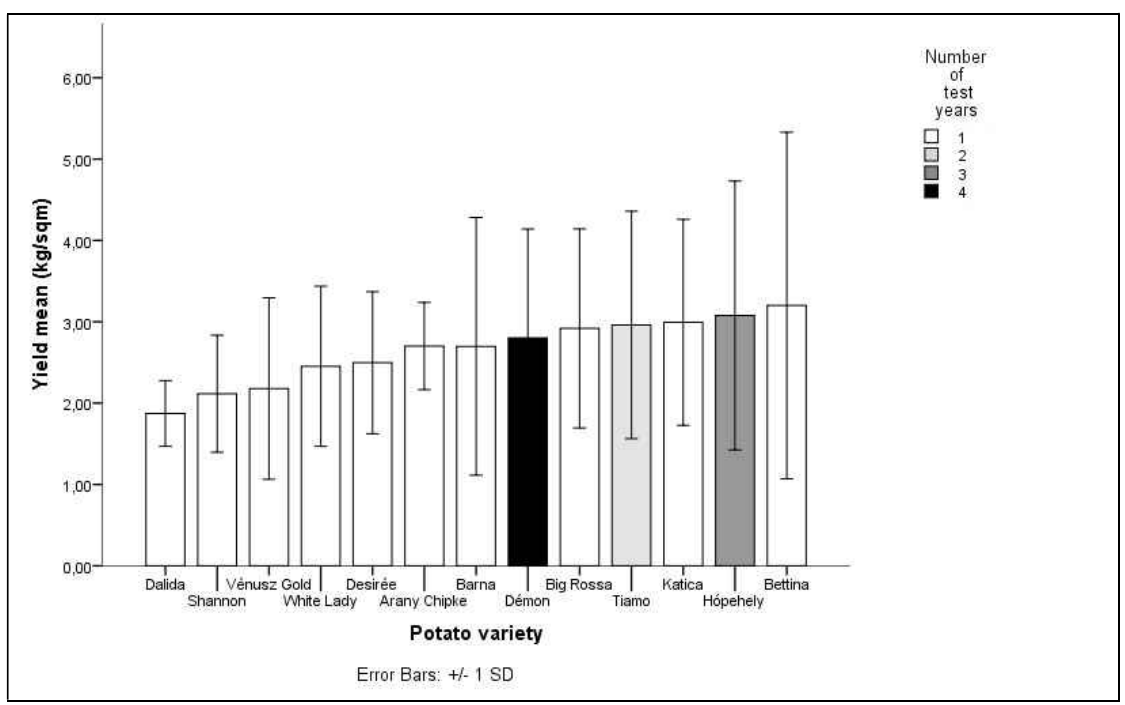

Figure 2. Average yield of varieties tested in $2012-2015\left(\mathrm{~kg} / \mathrm{m}^{2}\right)$ 
There were big differences among the varieties' average yield production (Figure 2), although the differences were not significant. Yield results were compared with parameters of trial sites and technologies, and moderate strong correlation was found with the $\mathrm{pH}$ level of the soils, $r_{s}(99)=.347, \mathrm{p}<.01$. The higher the $\mathrm{pH}$ level was, the more yield was measured.

\section{Results of qualitative parameters}

The most common quality problem was common scab (Streptomyces spp.) infection (average 15.9\%). The damage of pests $(6.23 \%)$ and Rhizoctonia infection (5.9\%) occurred on a lower level (Figure 3).

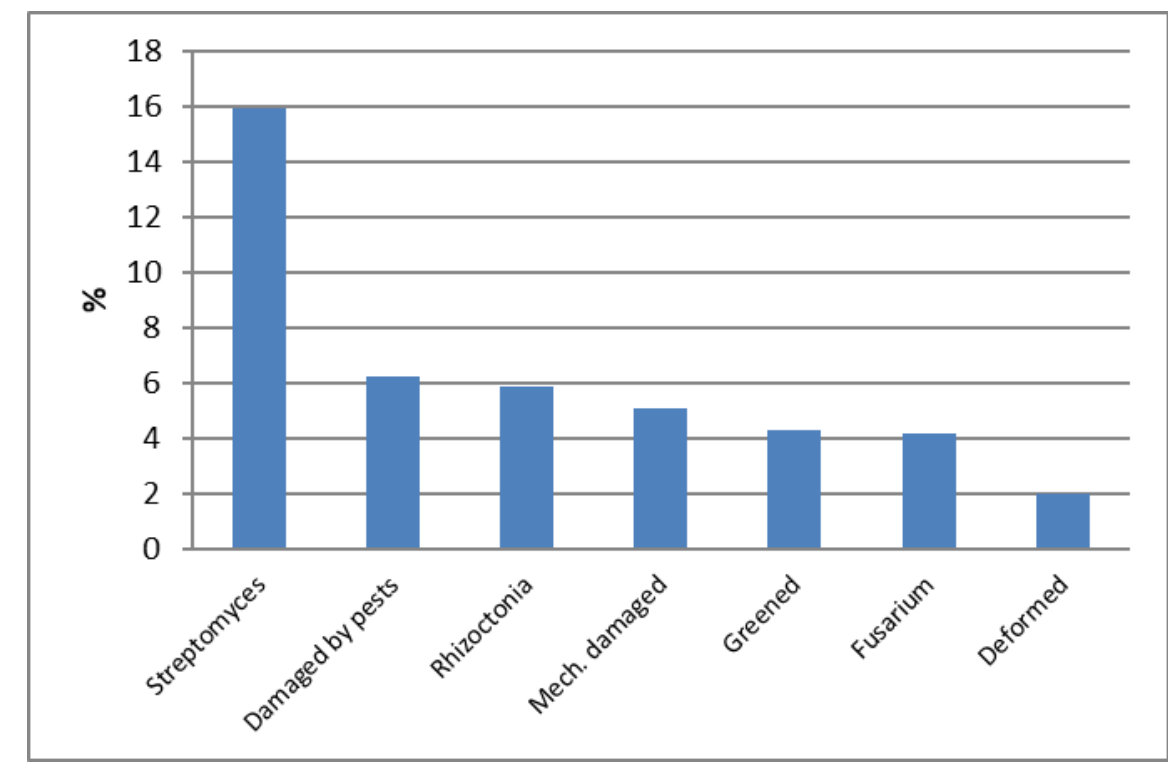

Figure 3. Average proportion of tubers with quality problems (all varieties, all years, data of 14 farms)

\section{Common scab (Streptomyces spp.)}

Among the eight measured quality problems the common scab (Streptomyces spp.) infection proved to be the most frequent problem in all of the four years. This disease causes serious problems for both organic and conventional cultivation, but its severity may be different (TEIN ET AL., 2015). Scab resistance may differ among varieties and using resistant varieties is the most reliable control method for common scab (DEES AND WANNER, 2012; WANNER AND KIRK, 2015). Since the tested varieties are results of conventional breeding programs, their resistance might not be valid for organic cultivation. In our trials the varieties showed different scab infections not only compared to each other but also compared to the breeders' variety descriptions (Table 2).

Among the varieties tested in more than one year, the least infected tubers were found in samples of 'Hópehely' (2.74\%, average of 3 years), the most were in samples of 'Démon' (19.84\%, average of 4 year). There were no statistically significant differences among the susceptibility of varieties.

\section{Pest damage}

Among the eight quality problems the damage of several insect and non-insect pests (Agriotes and Gryllotalpa larvae, slugs) was the second most common problem. The highest degree of damage appeared in 2013. Presumably, the pests were looking for water in the tubers, since it was a very dry season. Regarding the all of four years, the most frequent pest damage was caused by the larvae of Gryllotalpa gryllotalpa. As source of 
Review on Agriculture and Rural Development 2018 vol. 7 (1-2) ISSN 2063-4803

infection, the farmers marked the applied compost and farmyard-manure. The pest management against European mole cricket is a difficult challenge for organic growers.

Table 2. Evaluation of varieties' resistance to common scab according to organic on-farm trial results vs. conventional references

\begin{tabular}{|c|c|c|c|}
\hline Variety name & $\begin{array}{c}\text { Resistance to common scab } \\
\text { according to references } \\
\text { (Scale - where appropriate -of } \\
1 \text { to } 9 \text {, where } 9 \text { is most } \\
\text { desirable) }\end{array}$ & $\begin{array}{c}\text { Average infection } \\
\text { rate in our trials } \\
(\%)\end{array}$ & $\begin{array}{l}\text { Trials' experiences } \\
\text { compared to } \\
\text { references }\end{array}$ \\
\hline Arany Chipke & resistant & 14.29 & $\downarrow$ \\
\hline Barna & resistance to common scab: 6 & 18.00 & $\downarrow$ \\
\hline Bettina & resistance to common scab: high & 6.33 & $\rightarrow$ \\
\hline Big Rossa & $\begin{array}{l}\text { resistance to common scab: } \\
\text { medium - good }\end{array}$ & 9.63 & $\rightarrow$ \\
\hline Dalida & resistance to common scab: 7 & 4.00 & $\uparrow$ \\
\hline Desirée & resistance to common scab: 4 & 9.33 & $\uparrow$ \\
\hline Démon & resistant & 9.92 & $\downarrow$ \\
\hline Hópehely & resistance: medium & 1.37 & $\uparrow$ \\
\hline Katica & resistant & 3.00 & $\rightarrow$ \\
\hline Shannon & resistance to common scab: 7 & 13.13 & $\downarrow$ \\
\hline Tiamo & resistance to common scab: 7,5 & 8.80 & $\rightarrow$ \\
\hline Vénusz Gold & resistant & 4.4 & $\rightarrow$ \\
\hline White Lady & resistant & 2.2 & $\rightarrow$ \\
\hline
\end{tabular}

Source: Papp, 2016

\section{Black scurf (Rhizoctonia solani)}

Among the eight quality problems black scurf (Rhizoctonia solani) infection was the third most common during the four years of the trial. The varieties showed different susceptibility to Rhizoctonia, however, the differences were not significant. The proportion of infected tubers was highest in the samples of 'Big Rossa' (15.18\%, tested in one year), and there was no infection in samples of 'Arany Chipke' and 'Katica'.

\section{CONCLUSIONS}

The following conclusions can be drawn from the study:

- On-farm participatory research is a very useful approach to generate practical information on the agronomic characteristics of varieties. Due to the variety of soils and cultivation methods used on the participating farm-sites, we could get meaningful information on varieties' performance.

- Regarding all of the data in all of the four years, the most common quality problems of Hungarian organic potato production were common scab (Streptomyces spp.) infection, damage of pests and Rhizoctonia infection.

- Yield results compared with parameters of trial sites and technologies, moderate strong correlation was found with the $\mathrm{pH}$ level of the soils.

- Our results regarding common scab resistance were different from variety descriptions given by seed tuber distributers in many cases, so variety testing in organic farming proved to be useful.

- After summarizing the data of the four-year trials, the best performing varieties were proposed to farmers according to specific characteristics of their farms.

- Throughout the management process of the on-farm program we collected unique 
information about the Hungarian organic potato sector - there were no research data available on this issue on national-scale before. Further research topics could be identified based on these new data in cooperation with farmers.

- There were big differences among involved farms regarding yield and quality parameters. During the trials, apart from the scientific work, knowledge-exchange could also be implemented to improve farm yields.

- Besides summarizing and sharing research results, regular meetings and field trips were arranged for farmers and other stakeholders of the potato supply chain. Communication was highly improved among the participants and a well-working organic potato workgroup was formed.

\section{ACKNOWLEDGEMENTS}

The authors would like to thank all the farmers for their enthusiasm, openness and lots of work. Thanks to Zsolt Polgár (Potato Research Institute, Hungary) for his support through the whole project and for Bernhard Speiser (FiBL Switzerland) for helping to start the project. Also thanks to all of the merchandizers who offered the potato tubers to the project for free.

\section{REFERENCES}

Dees, W.M., Wanner, A.L. (2012): In Search of Better Management of Potato Common Scab. Potato Research 55: 249-268.

KovÁcs, G., Kótai, Cs., Kanyó, Zs., Láng, L., Nagyné, K.R., Polgár, Zs., Roszík, P., Zsigrai, Gy. (2006): Kisparcellás kísérletekre alapozott ajánlati fajtalista készítése ökológiai gazdaságok számára. In: Ökológiai termesztésre alkalmas szántóföldi növényfajták kiválasztása. Biokontroll Hungária Kht., Budapest. Pp. 39-82.

PAPP, O. (2016): Qualitative assessment of resistant main-crop potato varieties on Hungarian organic farms. Poster presented at: International Conference on Conservation Agriculture and Sustainable Land Use (CASLU), (Budapest, Hungary, 2016.05.31.).

Tein, B., Kauer, K., Runno-Paurson, E., Eremeev, V., Luik, A., Selge, A., Loit, E. (2015): The potato tuber disease occurence as affected by conventional and organic farming systems. Americal Journal of Potato Research 92(6): 662-672.

WANNER, L.A., KIRK, W.W. (2015): Streptomyces - from Basic Microbiology to Role as a Plant Pathogen. Americal Journal of Potato Research 92(2): 236-242. 